\title{
THE CREATING OF PERSONNEL STRATEGY AND ITS IMPLEMENTATION TO ORGANIZATION XYZ
}

\author{
Lenka Kempová ${ }^{1}$ \\ ${ }^{1}$ Slezská univerzita, Obchodně podnikatelská fakulta, Univerzitní nám. 1934/3, 73340 Karviná \\ Email:lenka.kempova@seznam.cz
}

\begin{abstract}
This paper is focused on creation of personnel strategy and its implementation in organization XYZ. ${ }^{1}$ The personnel strategy must have a clear continuity on the startegy of the company. By this personnel strategy is further defined all the activities of the organization, which are connected with the human resources management. The first part is focused on demarcation of the basic concepts and approaches to define the personnel strategy, the second part describes the priorities of the organization XYZ management, starting points of the personnel strategy, its implementation and control mechanisms. In the conclusion, there are introduced some outputs of the XYZ's personnel strategy. The aim of this paper is to describe the creation of the personnel strategy and further to capture the experiences from its implementation in XYZ and therefore to help other organizations recently or possibly interested in this field.
\end{abstract}

Keywords: human capital, human resources, implementation of personnel strategy, personnel strategy.

JEL classification: M12, M50

Doručeno redakci: 3.10.2012; Recenzováno: 18.2.2013; 4.3.2013; Schváleno k publikování: 16.4.2013

\section{Introduction}

Present time is characterized by the permanent changes. These changes do not appear only in politics, technologies, demographic situation etc. but simultaneously in increasing demands on thinking, acting and behaviour of the senior employees and common employees too. The organization can't miss the educated, progressive and motivated people, so the systematic approach to human resources management as the source of the competitive advantage is still more and more important.

Such changes hit also the XYZ, so the management decided to react by the implementation of systematic approach whose integral part must be definiton and realization of organization strategy, including the personnel strategy.

The paper is divided into two parts. The first one introduces the theoretical resources, which might serve as the starting point for personnel strategy creation. The second part studies the knowledge and problematics of the practical implementation of the personnel strategy. This part focuses, except other, also on practical use of personnel strategy, the XYZ's management priorities, on resources (internal and external), which affect the company by its management and the estimated aims and activities fulfilling these aims including the control mechanisms. In the conclusion, there are presented some outputs of the XYZ's personnel strategy for the present period.

\footnotetext{
${ }^{1}$ The Public Administration Organization, whose background I used for this paper, does not want to be named with the official name. For this reason I used the name "XYZ".
} 


\section{The starting points}

Increasing the quality of the offered services is unimaginable without setting the aims and simultaneously the ways to fulfill them, thus setting the company's strategy. The concept of organization's strategy might be defined by several ways. For example, according to Lubasová (2004) it means ,setting the long-term basic aims of the organization and estimation of the essential steps and sources to fulfill these goals“. Other authors (Plamínek, Fišer, 2005, p. 80) say: „only from the organization's strategy we can unroll the definition of the majority of the organization's processes and from this subsequently define the sources and ways needed to ensure the fulfilling them."

The organization's strategy is the basic pillar on which continue all other strategies in the organization. One of the most important is the personnel strategy, which represents the basis of the work with human resources and which is further described in detail in this paper.

Even for the name personnel strategy exist several definitions, for example according to Urban (2003, p. 124) it expresses ,long-term organization's aims in area of using the working sources and its economy..." while ,... its compartments are usually also the ways, methods and steps leading to reach the estimated goals". According to his opinion, to formulate the personnel strategy means ,... to find the aswers on basic questions of the medium-term personnel developement of the organization: how many employees will be needed, what should be their qualifying and educational profile, by what way they will be hired, how will they be led, motivated and trained, how will they be rated and what will be their common basic values."

The main content demarcation of personnel strategy, where the strategy is needed to be elaborated, are as follows: forming the organization's manpower, developement and education of employees, rewarding the employees and the employee relations.

In the phrame of creating and realization of the personnel strategy it is needed to earmark 3 basic phases:

1. phase - execution of the analysis to retrieve the entries for the strategic management process,

2. phase - selection and formulation of the strategy,

3. phase - implementation of the strategy.

The aim of this work is to describe briefly the creation of the personnel strategy and consequently capture the experiences from its implementation in XYZ, which to help other organization as well, which are or will be involved in this topic.

\section{Approaches to formulate and realization of the personnel strategy}

When creating a personnel strategy it is possible to use various procedures. Simultaneously it is neccesary to pay an outstanding attention to the future developement because in future the people will work with a higher rate of uncertainty then they used to work in past. As the internal and external conditions of organization's activities change, this must reflect the changes flexibly. The personnel strategy should be created with sufficient cooperation of the organization's leaders.

When formulating the personnel strategy, it is neccesary to answer on three basic questions:

1) What is the recent status of the organization?

2) What is the desired status of the organization in one, two, three or five years?

3) How will the organization reach the desired status? 
Figure 1: The personnel strategy model showing the procedure, how to aswer these questions

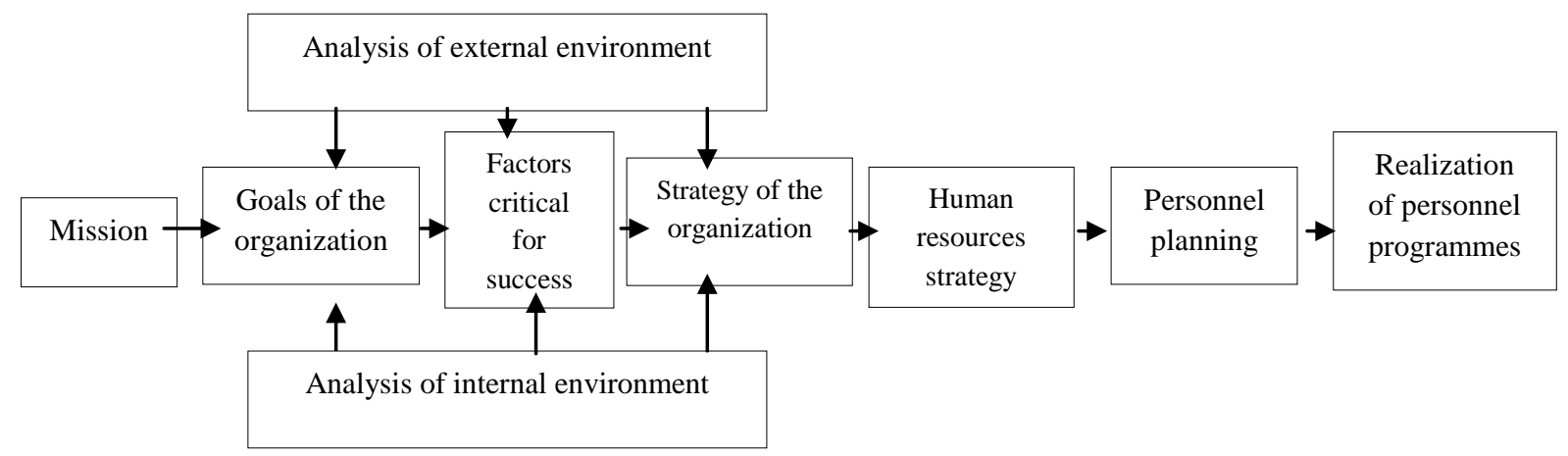

Source: Personální analýza, plánování a strategie - manuál (Lubasová, 2004, p. 180)

The presumption for the elaboration of the personnel strategy is the revision or analysis, respectively, of the recent state of the personnel situation in the organization. The purpose of the analysis is to help to understand the problem of the human resources in the orgnization in the future and further to identify, classify and understand the essential factors, which in this area must necessarily affect the organization's strategic decisions.

It is possible to use the SWOT analysis of the organization as a methodological guidance or to use the analysis of the branch, analysis of the resources and competition's abilities, analysis of the organization's culture, etc.

The implementation of the strategy into practice may shipwreck on unclear formulation of the strategic aims, on insufficiently elaborated procedures of particular steps, on weak motivation of the employees, etc. Also the attitude of the leading employees are crucial same like their identification with the strategy.

The strategy realization might be facilitated by (according to Lubasová, 2004):

- a precise formulation of the strategic goals,

- high qualification of the employees,

- continuing in recent customs, employees' behaviour,

- sufficient time for the preparation and elaboration of the particulalr strategic steps,

- assesment of each strategic step from the aspect of its benefit to fulfill the strategic goal,

- well designed information system and related informing all employees with the vision and strategic goals,

- possibility of the strategic operations and creating the atmosphere for fulfilling the strategic operations (ensure the understanding of neccesity of strategy and identification of the employees with the strategic aims, etc.).

\section{The purpose and the priorities of the personnel strategy}

Personnel strategy represents the essential element of the XYZ personnel politics to fulfill the organization's strategy, priorities and the strategic goals through the human resources. It consists of the complex of specific activities, which support the fulfilling or directly fulfill the priorities and strategic aims and is determined for all the employees. Personnel strategy is based on and closely continues on strategic documents of $\mathrm{XYZ}$ and is estimated within the period $2012-2017$. 
The XYZ leadership priorities on strategic level were defined in following structure: mission, vision, respected values, from whose were consequently derived the main strategic goals. Main strategic goals aimed at fulfilling the priorities of XZY's management are e.g. the overall implementation of principles of the organization's proper quality management, creation of a positive public image, creation of a corruption preventing environment, emphasis on employee proficiency, raising the efficiency of personnel processes and using the personnel tools to maintain quality standards and promote higher employee efficiency and motivation. The last three of the aforementioned relate directly to personnel strategy. Below the keys elements which were defined as a background for the XYZ's strategy creation are given.

Strategic level - Mission - and its defined key elements: legislator's will - client, citizen, public - effectivity. From the strategic level - Vision - were for the personnel strategy defined these key elements: open, willing and client-oriented organization - team work and communication - professionalism - effectiveness - solidarity and loyalty.

From the strategic level - Respected values - were for the personnel strategy defined these key elements: openness, transparency (we are open, transparent and willing to participate in creating values together with interested parties) - customer access (our aim is to fulfil every justifiable expectation, demand or need of the client) - professionalism (we provide services at high proficiency level and in accord with the principle of strict impartiality; each task is performed with assurance and responsibility) - solidarity and loyalty (we consider one of our primary tasks to be the stimulation of employee involvement and the assurance of a high quality of our services) - effectiveness (we work quickly, effectively and economically).

From the strategic levels listed above - Mission, Vision and Respected values - there were derived following main strategic intensions and priorities of organization XYZ's direction in the personnel area representing significant entry for personnel strategy creation. The main strategic goals: Good administrative of the public affairs - effectiveness - team work and communication - professionalism - solidarity and loyalty. Priorities of organization's guidance in the personnel area: ratings, motivation and remuneration of the employees. Creation of the personnel strategy has been financed by EU, the total cost has amounted to 260.000,- CZK.

\section{Starting point of the personnel strategy}

Conditions of the personnel operation are changing constantly, some factors evolve slowly, others might be characterized as fast changes. External and internal factors together determine and influence the form of the personnel strategy.

Into the external factors significantly influencing the form of the personnel strategy belong: startegic documents - legislative changes with direct impact on personnel work demographic developement of the citizens - situation on the labor market - educational level of the high school and university graduates.

To the internal factors we can include those areas which are linked with the activities of the personnel department, which is considered to be a bearer of the personnel strategy. Past activities and recent state of personnel activities in XYZ directly determine the final form of the personnel strategy. 


\subsection{Analysis of the present state}

The present state analysis of the personnel area was described by:

A. description of present state of the personnel management - SWOT analysis,

B. description of personnel area through the chosen parameters - number of employees, demographic structure, employee motivation, development and education.

\section{SWOT analysis}

Represents the evaluation of present state of the personnel area, covers the perion until the end of 2011in the following structure:

+ the strong features of the personnel management

- space for improvements in the personnel management in the present

+ opportunities for the personnel management in the following period

- threats for the personnel management, which might appear in the following period

Space for the improvements, opportunities and threats of the following period represented the significant source of information and were creating the essential entry when the personnel strategy was being created. The SWOT analysis has been carried out using the outputs of following analyses and methods - the analysis of internal resources and capacities of the organization which included e.g. benchmarking outputs, strategic documents analysis outputs and the outcomes of a human resources planning analysis as well as an analysis of need development.

Table 1: SWOT analysis - states some outputs of analysis of the personnel management in $\mathrm{XYZ}$

\begin{tabular}{|c|c|}
\hline Strengths & Weaknesses \\
\hline $\begin{array}{ll}\text { - } & \text { application of up-to-date software tools } \\
\text { - } & \text { stable personnel staffing } \\
\text { - } & \text { support from the organisation's management } \\
\text { - } & \text { constant improvement and initiative } \\
\text { - } & \text { use of financial means from the EU }\end{array}$ & $\begin{array}{l}\text { - } \text { development and education-based evaluation } \\
\text { - } \quad \text { out-dated system of evaluation } \\
\text { - } \quad \text { lacking method of adaptive process } \\
\text { (sport and social events) } \\
\quad \ldots\end{array}$ \\
\hline Opportunities & Threats \\
\hline $\begin{array}{ll}\text { - } & \text { use of financial means from the EU } \\
\text { - } & \text { quality improvement in choice of employees } \\
\text {. } & \text {. }\end{array}$ & $\begin{array}{ll}\text { - } & \text { changing legislation } \\
\text { - } & \text { labour market situation } \\
\text { - } & \quad \text {.. }\end{array}$ \\
\hline
\end{tabular}

Source: organization XYZ.

\section{The personnel area description through the chosen parameters}

Important entry when creating the personnel strategy was also the description of the personnel area with help of certain parameters and captured trends. This description represented other view on the whole area of the XYZ's personnel management, which captures its developement in period $2008-2010$.

\subsection{The Personnel Department's Ambitions}

Other important entry when creating the personnels strategy consists of the personnel department's ambition itself. The ambitions are divided into 5 basic circles:

- to teach the employees how to use new IT tools, team work, etc.,

- work with the information with emphasis on the personnel department's successes visibility, electronic communication maximalization, etc.,

- to ensure the organization's strategic aims in a personnel area: personnel's department accessibility, mapping and effectiveness of processes in a personnel area, etc., 
- support to competences transfer in organization's hierarchy downwards,

- to search for external financial sources including sources of EU.

\subsection{The Personnel Department's Priorities}

Ambitions of the personnel department were transformed into personnel department's priorities for the following period and they were defined as follows:

- new rating system implementation,

- increasing the managing skills of the senior employees,

- improving the interpersonal relations,

- reciprocal linking of the personnel activities,

- personnel marketing in and out of the organization,

- using the EU financial sources, etc.

\subsection{Continuing activities in personnel strategy}

Created personnel strategy links directly to personnel activities, which were implemented before 2012 .

To the most important belong:

- technological changes (for example personnel information system modification),

- strengthening the employee care area (for example implementation 4 weeks long compensatory period, improving the working environment, etc.),

- more attention dedicated to employees growth (for example possibility to increase the qualification),

- increasing the quality and effectiveness (for example with implementation of new tools increasing the quality).

\section{Personnel strategy and its fulfillment - personnel strategy implementation}

\subsection{Personnel Strategy}

Pursuant all the previous entries the personnel strategy was created to be one of the subsections of the organization and consists of three main aims.

Table 2: The personnel strategy goals - shows the aims of the XYZ's personnel strategy

\begin{tabular}{|c|l|c|}
\hline Goal & Goal & Goal \\
A PROFESSIONAL & THE EFFECTIVENESS & USE HUMAN RESOURCES TOOLS TO \\
EMPLOYEE & $\begin{array}{c}\text { OF HUMANOVE THE QUALITY, THE } \\
\text { PROCESSES }\end{array}$ & $\begin{array}{c}\text { PERFORMANCE AND THE MOTIVATION } \\
\text { OF EMPLOYEES }\end{array}$ \\
\hline
\end{tabular}

Source: organization XYZ.

Each of the aims contains amount of partial aims; each partial aim is connected to activities for its fulfillment. Individual activities are elaborated to a form of specific action plan showing the date of fulfilling, see below. 


\subsection{Fractional Aims of Personnel Strategy}

Table 3: Fractional Aims of Personnel Strategy - Shows some fractional aims of XYZ's personnel strategy

\begin{tabular}{|c|c|c|}
\hline $\begin{array}{l}\text { A PROFESSIONAL } \\
\text { EMPLOYEE }\end{array}$ & $\begin{array}{l}\text { Goal } \\
\text { THE EFFECTIVENESS OF } \\
\text { HUMAN RESOURCES } \\
\text { PROCESSES }\end{array}$ & $\begin{array}{l}\text { Goal } \\
\text { USE HUMAN RESOURCES TOOLS TO } \\
\text { IMPROVE THE QUALITY, THE } \\
\text { PERFORMANCE AND THE } \\
\text { MOTIVATION OF EMPLOYEES }\end{array}$ \\
\hline Subgoals & Subgoals & Subgoals \\
\hline expertise & $\begin{array}{l}\text { accessibility of the HR's } \\
\text { services }\end{array}$ & a new system for adapting new employees \\
\hline development and education & $\begin{array}{l}\text { mapping and improving } \\
\text { human resources processes }\end{array}$ & $\begin{array}{l}\text { modification of the system used to choose } \\
\text { employees }\end{array}$ \\
\hline developing managerial skills & $\begin{array}{l}\text { maximizing electronic } \\
\text { communication }\end{array}$ & $\cdots$ \\
\hline
\end{tabular}

Source: organization XYZ.

\subsection{Activities for fulfilling of individual aims}

Table 4: Activities for fulfilling aim - Personnel tools as quality support, output support and employee motivation show the example of activities for fulfilling the individual aim „new system of new employee adaptation"

\begin{tabular}{|c|c|c|c|c|}
\hline \multicolumn{5}{|l|}{ Goal } \\
\hline Subgoal & Activity & Sequential steps & Due date & Note \\
\hline \multirow{4}{*}{$\begin{array}{c}\text { a new system } \\
\text { for adapting } \\
\text { new } \\
\text { employees }\end{array}$} & \multirow{4}{*}{$\begin{array}{l}\text { the } \\
\text { implementation } \\
\text { of the new } \\
\text { adaptation } \\
\text { process system }\end{array}$} & mentor training & 31. 3. 2012 & done \\
\hline & & $\begin{array}{l}\text { modifying the human resources information } \\
\text { system to support the adaptation system }\end{array}$ & 31. 8. 2012 & done \\
\hline & & $\begin{array}{c}\text { implement the adaptation system into day-to-day } \\
\text { practice }\end{array}$ & 31. 8. 2012 & done \\
\hline & & $\begin{array}{l}\text { evaluating experiences and feedback from the } \\
\text { adaptation process }\end{array}$ & 31. 3. 2013 & $\cdots$ \\
\hline
\end{tabular}

Source: organization XYZ.

\section{The control mechanisms for management of personnel strategy}

The control of fulfilling the strategy, its prospective modifications and actualization will be solved by regular annual evaluation of personnel strategy's procedure, which will be executed always in January. Annual evaluation of personnel strategy's fulfilling will be assessed by the group which also took part in creation of personnel strategy.

Output of personnel strategy fulfilling annual evaluation will be:

- control of fulfilling individual activities prepared for fulfilling individual aims of the personnel strategy,

- prospective modification of individual activities of action plan or date of its fulfillment, 
- prospective actualization of perosonnel startegy compartments reacting on the change of XYZ's strategy, priorities and goals.

\section{Conclusion}

Dynamic evolution of the society brings much higher rate of uncertainty then it used to be relatively recently, for this reason the personnel strategy must be not only long stable, but it also must flexibly reflect continuous evolution considering the changes of internal and external environment of the organization.

Personnel strategy watches the enforcements of changes in the organization like a unit with the aim to redirect the organization's thinking and values and to change its culture. Beside the organization's strategy the personnel strategy should have the links also to mission, vision, respected values, but also the culture, style of management and the whole organization's image. However, newly created personnel strategy is the beginning of the row of changes, which will be needed to be executed in personnel activities, to fit into the direction marked by this strategy. The most important step in creating the personnel strategy is to persuade the management about the importance and necessity of its implementation into practice, which was successful in this case.

It is now supposed the personnel work in XYZ thanks to newly created personnel strategy will move on, to a more modern and more effective style, which will help the organization to handle at least some problems now affecting the organization, same like with those which might appear in the future.

\section{References}

[1] ARMSTRONG, M., 2007. Řizení lidských zdrojů: Nejnovějši trendy a postupy. 10. vyd. Praha: Grada Publishing, 800 s. ISBN 978-80-247-1407-3.

[2] BARTOŇKOVÁ, H., 2010. Firemní vzdělávání. Praha: Grada Publishing, 208 s. ISBN 978-80-247-2914-5.

[3] BEDRNOVÁ, E., I. NOVÝ a kol., 2009. Psychologie a sociologie ř́zení. Praha: Management Press, 800 s. ISBN 978-80-7261-169-0.

[4] DVOŘÁKOVÁ, Z. a kol., 2007. Management lidských zdrojů. 1. vyd. Praha: C. H. Beck. ISBN 978-80-7179-893-4.

[5] DVOŘÁKOVÁ, Z., et al., 2004. Slovnik pojmů k ř́zení lidských zdrojů. Praha: C. H. Beck, 192 s. ISBN 80-7179-468-6.

[6] HRONÍK, F., 2007. Rozvoj a vzdělávání pracovniků. 1. vyd. Praha: Grada, 233 s. ISBN 9788024714578.

[7] KEŘKOVSKÝ, M. a O. VYKYPĚL, 2002. Strategické ř́zení: teorie pro praxi. Praha: C. H. Beck, 172 s. ISBN 80-7179-578-X.

[8] KOCIÁNOVÁ, R., 2010. Personální činnosti a metody personální práce. Praha: Grada Publishing, 215 s. ISBN 978-80-247-2497-3.

[9] KOUBEK, J., 2007. Řízení lidských zdrojů: Základy moderní personalistiky. Praha: Management Press, 399 s. ISBN 978-80-72611-68-3.

[10] KOUBEK, J., 2000. ABC praktické personalistiky. Praha, Linde. ISBN 80-86131-25-4. 
[11] KOUBEK, J., 2007. Personálni práce v malých a středních firmách. 3. rozšířené a aktualizované vyd. Praha: Grada, 261 s. ISBN 9788024722023.

[12] KUBEŠ, M., D. SPILLEROVÁ a R. KURNICKÝ, 2004. Manažerské kompetence. Způsobilosti výjimečných manažerů. Praha: Grada Publishing, 184 s. ISBN 80-2470698-9.

[13] LUBASOVÁ, A., 2004. Personální analýza, plánování a strategie - manuál. Brno: FSS.

[14] PALÁN, Z., 2002. Výkladový slovník lidské zdroje. Praha: Academia. ISBN 80-2000950-7.

[15] URBAN, J., 2003. Řizení lidí v organizaci. Personální rozměr managementu. Praha: ASPI Publishing, 300 s. ISBN 80-86395-46-4.

[16] VODÁK, J. a A. KUCHARČÍKOVÁ, 2007. Efektivní vzdělávání zaměstnancư. Praha: Grada Publishing, 212 s. ISBN 978-80-247-1904-7. 